\title{
Research on English Teaching Method based on English Culture
}

\author{
Wu Chen \\ Xi’an Shiyou University, Xi’an, Shaanxi, 710065
}

Keywords: English Culture, Cultural Teaching, Method.

\begin{abstract}
Culture and language have a very close relationship, especially in English this culture is very strong language. Therefore, in English teaching to strengthen English culture teaching, not only to help students correctly use English, but also help students improve their English communication skills. However, the current situation of English teaching in our country, many schools in the degree of emphasis on the teaching of English culture is not enough, resulting in English teaching confined to the appearance of teaching a lack of cultural connotation, English teaching efficiency is not high enough. At present, the social demand for talent is getting higher and higher, and English ability is one of the measurement standards of talents. It is very important to use effective English culture teaching method to improve students' ability of learning English and English. In this paper, the author mainly analyzes the current teaching methods of English culture, and puts forward some methods and strategies of English culture teaching, hoping to provide reference and suggestions for the future English education reform.
\end{abstract}

\section{Introduction}

Professor Wang Zuoliang, a well-known British literary research expert, once said, "It is very important to cultivate students' cultural consciousness to learn a language in a way that does not understand the social culture of language, and the so-called cultural consciousness mainly includes Cultural understanding, cultural knowledge and cross-cultural awareness and ability. Therefore, English teachers have infiltrated English cultural knowledge into practice teaching and cultivated their students 'cultural consciousness, which is very important for the improvement of students' practical ability in English communication. Speaking of English teaching and English culture will be closely integrated with the future of English teaching reform is the inevitable trend, but also an effective way to improve English teaching efficiency.

\section{Analysis of English Culture in English Teaching}

Cultural factors have always been regarded as an important part of English teaching, but from our promulgated a variety of English teaching documents or outline point of view, the center of the main focus or language teaching, the importance of English culture teaching is not enough, but also There is no clear description of the teaching methods, teaching contents, teaching methods and teaching tests of English culture teaching, and there is no clear explanation of the methods of English teaching and English culture. Therefore, these reasons to a large extent led to the school, teachers and students of English culture teaching attention is not enough. In addition, many teachers have no experience and lack of relevant training work, the English culture itself is less understanding, teaching can not start, but English culture teaching is difficult to be used in English courses, English teaching efficiency Low, teaching quality is not high. At present, English teachers in the English teaching process, pay more attention to the basic knowledge of students learning and language skills training, for the English cultural knowledge and other aspects of teaching, so educated students in the way of thinking, religious beliefs, behavior Habits and values and other aspects of cultural knowledge know little, resulting in their practice in English often do not know the wrong. 


\section{English Culture Teaching Ideas}

In general, cultural teaching we mainly divided into two kinds of methods, namely the traditional cultural knowledge transfer method and the new cultural process teaching method of these two teaching methods. Cultural knowledge transfer method is mainly the teaching process which will be some of the country's historical geography, literature and art, religious politics, laws and regulations and food and clothing practices and other cultural knowledge to students, and to attract the attention of students, to stimulate students to learn initiative and Enthusiasm, so that students master the culture at the same time cultivate students from the cultural awareness. However, the traditional teaching methods of cultural knowledge have been criticized by experts and scholars because they think that this teaching method and language teaching there is a separation, teaching a lack of certain system, it is possible for students to form a culture Of prejudice or prejudice, is very detrimental to the realization of the ultimate goal of cultivating students' cultural awareness. In fact, I believe that cultural teaching is inseparable from the language teaching, language teaching is inseparable from the cultural teaching, appropriate language teaching and cultural teaching is the key combination of organic. First of all, in the process of English teaching English teaching content designed by the basic cultural facts taught to students, so that students learn the knowledge of English culture has a preliminary understanding and understanding. Secondly, in the English teaching which adopts the teaching method of English culture process, the English culture is regarded as a social tectonic system. At all stages of the English learning of the students, it always runs through the teaching of English cultural knowledge and cultivates the students' English cultural knowledge. At the same time, Multi-faceted training students from the English cultural awareness, and effectively improve the level of cross-cultural sensitivity of students.

\section{Specific Suggestions for English Culture Teaching}

Regardless of what kind of teaching methods, should be based on the realization of teaching objectives as a prerequisite, and the realization of teaching objectives is the completion of teaching content as a way to English culture and English teaching effective combination of English teaching which should focus on teaching The contents of the English cultural knowledge to explain and introduce the cultural knowledge into the English knowledge of the explanation, in the training of students 'English ability at the same time cultivate students' English cultural awareness. For example, teachers in the English knowledge of the teaching process, will be related to knowledge points related to English cultural background water conservation to students. In the same time, the lecturer will explain the vocabulary related cultural background story to the students, which not only deepen the students' memory of the vocabulary, but also indirectly to the vocabulary of the use of the scene taught to the students, effectively improve the Practice Ability of Students' English Vocabulary. Therefore, teachers should pay attention to the introduction and explanation of the cultural background knowledge related to the text, strengthen the summary and accumulation of the relevant cultural knowledge in the course of preparation, and improve their English culture knowledge and English language teaching experience.

Multimedia as one of the modern teaching techniques, which combines video, animation, sound and other media information in one, the multimedia technology used in English culture teaching, through the multimedia so that students more intuitive feel the English culture, the real understanding of English knowledge The cultural meaning. Therefore, the English teachers should design English teaching courseware, in the English teaching content with some English cultural connotation of the picture, video and audio, through the multimedia technology to make English culture teaching become vivid, but also to enable students to better Master the connotation of relevant English cultural knowledge. However, it should be noted that the application of multimedia technology in the process of English culture should pay attention to the principle of appropriate, multimedia courseware content must also be closely linked to the content of English teaching, multimedia, the whole session of the English teaching time should be controlled in one third , 
Because the multimedia-assisted English cultural background of the introduction of this is to stimulate students to learn English culture of interest, to help students improve their English communication skills, such as teaching too much use of multimedia technology teaching, but will affect students learning English knowledge, Is not conducive to the improvement of students' English skills. At the same time, teachers should be more on multimedia courses to sum up, and strive to improve the multimedia English culture teaching deficiencies.

The characteristics of contemporary students' good love performance determine their favor for experiential activities, so teachers can inform students of the various types of English cultural activities in accordance with the teaching needs, inform the organization of some games, performances or experiences, and so on. Improve students' English cultural practice ability. For example, teachers can organize a number of such as English party, English games or English performances, students participate in these activities, personal experience and understanding of English cultural knowledge, better feel the English cultural differences. In recent years, foreign festivals have been sought by many students, teachers can festive party, so that students understand and experience the English-speaking countries of the holiday culture, so as to achieve the purpose of cultivating students' English cultural communication ability.

Many of the film and television works are rich in cultural connotations, in which the film and television works which contains a lot of tangible and intangible cultural knowledge, can be more vivid image reflects the social characteristics of English-speaking countries, and students watching TV works at the same time can feel inside Cultural differences, in the indirect improvement of their own English cultural knowledge at the same time, improve their own English cultural communication skills. For example, when teachers talk about the teaching content of ceremonial ceremonies in English, they can find some film and television works on the film and television works selection, so that students through repeated viewing of these film and television works, so that students feel the English-speaking country dining atmosphere, So that students can not only learn English language dining etiquette, but also allow students to master the English communication skills when eating.

Contrast teaching is a cross-cultural language teaching methods in the effective teaching methods, which is "there is more identification" performance. Through the contrast teaching, so that students feel the language difference between Chinese and English and cultural differences, distinguish between good English cultural communication characteristics. Therefore, teachers should actively collect some of the cultural knowledge and the corresponding English-speaking countries, the cultural content of the teaching content, classroom English textbooks designed English culture and national culture contrast. So that students learn the classroom at the same time feel the difference between English culture and local culture, so that students can learn the specificity of English culture, but also allow students to better understand and master English knowledge. For example, teachers can collect some foreign Christmas and foreign cultural differences between the Spring Festival characteristics, through the two festivals inside the shopping characteristics, wearing features and festivals and other songs compared to the cultural characteristics of English and Chinese, so that students better master English culture The

With the popularity of Internet technology, many schools are actively carrying out Internet teaching, such teaching methods not only cater to the development trend of society, but also meet the individual needs of contemporary students. Therefore, teachers should actively use the Internet to facilitate, fast, intuitive, large amount of information and other characteristics, as a modern English language teaching resources and means. First of all, teachers can guide students to browse some of the English culture on some of the historical geography, customs and habits of the English website, in the training of students 'English reading ability, but also improve the students' English culture knowledge. Second, teachers should be through WeChat, micro-blogging and QQ and other modern social software, from time to time for students in English way to push some of the cultural aspects of English knowledge, so that students receive knowledge of English knowledge of English culture. 


\section{Conclusion}

English culture is profound want to let students learn English, so that students master the corresponding knowledge of English culture is particularly important. Therefore, teachers should pay attention to the combination of English culture and English teaching, through the emphasis on teaching content of the English cultural background knowledge to explain the use of multimedia technology for English culture teaching, multi-organization students to participate in English cultural knowledge experience activities, the use of English film and television works so that students feel the English culture, to carry out Chinese culture and English culture for comparative teaching, the use of modern Internet for English culture teaching and other methods of voice English culture knowledge, improve students' English knowledge and practical ability.

\section{References}

[1] Chen Lei. Vocational English culture teaching methods [J]. Journal of Xingtai Vocational and Technical College, 2015 (04): 18-21.

[2] Gao Qingfang, Han Rong, Wang Bo. On the teaching method of college English classroom teaching [J]. Journal of Shaanxi Institute of Education, 2007 (02): 86-88.

[3] Liu Dailin, Zhang Jianyu. Study and reform of the current situation of public English teaching in higher vocational colleges [J]. Chinese Foreign Languages, 2009 (6)

[4] Su Guangcai, Meng Xin. College English cultural differences teaching methods empirical [J]. Foreign languages, 2014 (01): 133-135.

[5] Liu Ling. College English cross-cultural teaching model construction [J]. Campus English, 2014 (23): 49-49.

[6] Li early Xia. College English culture experience teaching research [D]. Shaanxi Normal University, 2012

[7] Wu Xiaoli. College English culture teaching present situation and countermeasures [J]. Development, 2013 (02): 123-124. 